UDK 339.727.22(497.11)

doi: $10.5937 /$ bastina30-25612

Originalni naučni rad

Lidija N. VUČIĆEVIĆ *

Evropski univerzitet Kallos Tuzla, Bosna i Hercegovina

AnkaS. BULATOVIĆ **

Evropski univerzitet Brčko distrikt, Brčko, Bosna i Hercegovina

\title{
SERBIA'S INVESTMENT FLOWS IN THE NETWORK OF GLOBAL INTERESTS
}

\begin{abstract}
Foreign investment as the form of financing does not only reflect its importance on a global but also on a national level of individual countries' economies. In the last two decades, Serbian foreign economic and political developments have undergone a tremolous but persistent struggle for integration into the world's economic trends. Generally speaking, it could be said that there is a diversity in motivation factors among the investors, as well as in overall effects on the host country's balance of payments (BoP) depending on the types of capital investment.

Serbia develops partnerships, and each partner has it's own interests and comparable advantages in the country, contributing to Serbia's better position in modern international relations. The aim of this paper is to emphasize Serbia's economic connecting with countries it cooperates with during the last several years, and lessons learned in the period of economic transition and bilateral interconnections.
\end{abstract}

Key words: investment trends, global interest, strategy, economy, politics.

\section{INTRODUCTION}

The processes of globalization or radical changes, initiating cooperation, free transfer of goods, services and capital, primarily promotes the variety of models of collaboration and regional or wider integrations. So, we have the European Union focusing on the rule of law, various types of support and increased investments, Russia aiming at energy and foreign affairs backing, the United States of America concentrating on security issues and China focused on infrastructure and markets. New economies offer new products, they look for energy sources and raw materials, and Serbia's "balancing" will continue until the process of

\footnotetext{
* Assistant Professor, lidijavucicevic55@gmail.com

** Professor, bulatovic.anka@gmail.com
} 
association with the European Union or harmonization of its policy with the European Union standards is completed, if it wants to acquire a full membership.

Regionalization not only represents the drawing of trade agreements but also the process influencing numerous spheres of the economic and social life. The best example is the European Union itself, established almost six decades ago and still developing and extending operational mechanisms.

Economic revival of the developing countries, as an alternative, includes the flow of foreign investments. Investments from the People's Republic of China make a significant investment flow in Serbia.

Serbian science and public are familiar with the Silk Road caravans, connecting Sian (Xi'an), one of the China capitals, with Europe and Russia, Central Asia and Middle East. The ancient main road for the exchange of goods, services and knowledge, as well as its indisputable influence on the Balkans, have not been sufficiently studied yet. To be precise, the refreshed idea of the Silk Road is becoming probably the most important perspective of the global economy development and also the geopolitical issue par excellence of the 21 st century ${ }^{1}$.

China has been promoting its "New Silk Road" initiative as a new development model for countries with accelerated economic development since 2013 (see: Simic, 2015: 196-216). China's ambitions have worried Western countries and adequate response to Beijing's strategy is being expected ${ }^{2}$.

The overall concept of international lending and general economic relations lead to a consensus that transitional countries have (un) willingly accepted: foreign investments are the main source for structural alignment of their economies with the global economic system (Avramović-Đukić, 2018:78).

\section{DETERMINANTS OF INVESTMENT FLOWS}

The basic requirements for attracting foreign direct investment includes an adequate legal and institutional framework. Laws and regulations ${ }^{3}$ should be attractive to potential investors, while institutional regulation should be a generator of economic growth and development.

1 Time will tell whether it is going to be par excellence - something infinitely better than anything we know

2 Chinese President Xi Jinping presented a vision of economic strengthening of the New Silk Road during his visit to Kazakhstan in September 2013. It was the first time that a strategic vision, recognized today as the construction of the economic belt and maritime route of the Silk Road for the 21 st century, was publicly presented .

3 Includes protection and clear determination of market players: investors, capital users, mediators and the government. For instance: defining the fields, types or the value of investment, obligation to employ local workforce, utilization of domestic resources (raw material, transport), then incentives and guarantees to investors. 
In the investment process the exporting and importing countries have different motives. The countries placing funds are primarily motivated by profit, then production expansion, overcoming barriers in international trading, transfer of technology and winning new markets. On the other side, the countries receiving capital are interested in overcoming the issue of lack of funds in order to increase their export, improving technical-technological equipment, using their natural resources, reducing unemployment and improving the standard of living.

Classification of foreign investments, according to types of investment, relates to:

- foreign direct investment

- joint ventures

- portfolio investment

- investment of funds through privatization

- concessions and built-operate-transfer (B.O.T.)

Lacking its own accumulation, the importing country uses concessions ${ }^{4}$ as an alternative type of foreign investment, particularly those related to infrastructure development whose effects depend on the field of given concession and the quality of contractual relations. Also, a foreign direct investment is considered acceptable type of investment if supported by long-term plans and introduces modern technologies and expertise.

The investment effects to the balance of payments depend on correlation between the flow of foreign direct investment and the increased value of imported equipment and new technologies. Therefore the capital importing country must have its role in creation of internal ambience in order to strengthen the positive effects and reduce or mitigate possible negative consequences. In addition, the fact that the liberalization of foreign direct investment policy does not necessarily mean diminishing a role of the government but reflects its redefined intervention roles and strengthening of the free market mechanisms, along with stronger efforts in achievement of country's economic and political stability (Ivić - Mitić, 2016:105).

A foreign investor's decision whether to place the funds is significantly influenced and defined by assessment of the global risks for doing business - economic (country risk) ${ }^{5}$ and political stability (political risk). Country risk of the anticipated investment involves the overall risk the investor is facing with in the

4 As a rule, the concessions are implemented by the following principles: equality, transparency, freedom of choice, free market competition and fair treatment.

5 Countries' risk assessments are often done for their needs by numerous banks around the world, specialized consulting firms, export insurance agencies and eminent professional journals (such as: Euromoney, Institutional Investor, etc.). 
country. Political risk relates to the risk of introduction of specific regulations in a country of investment, which may undermine or restrict investment activities (such as a request to invest in environmental projects or projects of common interest, or imposing a tax on foreign companies' profit) possibly resulting in the lack of further interest and termination of foreign company's operation in the host country. The term "risk" implies instability and uncertainty of the environment that is unfavorable to potential investors due to a reduced ability to plan the company's business activities. Risk factors are usually divided in three general categories (Ivić - Mitić, 2016:105):

- risks of general conditions (political, macroeconomic, social and environmental uncertainty)

- risks related to a specific industrial branch (industry specific)

- risks specific for a certain company (firm specific)

\section{GEOGRAPHICAL ASPECTS}

Geographic position of Serbia represents a link between East and West. No wonder the main actors on global scene (China, Russia, the European Union, the United States of America, Turkey) are interested in cooperation, although for very different reasons.

Serbia is a small continental country mostly positioned in South-East Europe while a smaller part lies in Central Europe that is the Pannonian Plain, with total area of $88.361 \mathrm{~km}^{2}$. Serbia holds an important position on the Danube and it belongs to the Danube River Basin that connects the country with the Black Sea, North and Baltic Seas over the Rhine-Main-Danube Canal, and with the Atlantic Ocean. Although with limited human (population of little over 7 million - Department of Economic and Social Affairs: "World Population Prospects: the 2017 Revision", p. 21), economic ${ }^{6}$ and military resources, Serbia strategically symbolizes the "Balkan Gate" and the "bridge" between East and West. One part of Serbia's territory - the Autonomous Province of Kosovo and Metohija - was put under the United Nations' jurisdiction following the armed conflict escalation and NATO military intervention in 1999, however it still remains an unresolved national issue with international aspect (Dimitrijević, 2017).

Qualitative definition of the term "small state", besides quantitative indications, takes into consideration some qualitative indicators that are, according

6 According to the most recent IMF estimates, the global economy will grow at a rate of $3.5 \%$ in 2019 and $3.6 \%$ in 2020 , up $0.2 \%$ and $0.1 \%$ lower than last year's forecasts . According to the same, in 2018 Serbia was second, among the countries in transition, in the inflow of foreign direct investments (according to: "World Investment Report 2019") 
to certain authors, measured as relative indicators of a country's size. Those indicators may be internal (political will - initiative, national interest, internally safe country, economic situation, relations with neighboring countries) and external (geostrategic position, strategic partners, membership in international organizations, membership in military alliances) (Tančić D., Gordić, Tančić P. 2018:406).

China is the second largest country in Asia and third largest in the world with total area of $9.597 .000 \mathrm{~km}^{2}$. The most populous country of the world with 1.4 billion residents ${ }^{7}$, which makes $1 / 5$ of total world's population and $1 / 3$ of total Asia population. According to its economic potential, China takes the second place in the world with a rapid growth rate („Rapid Growth of Chinese Economy”, Politika, January 19, 2018:2 $)^{8}$. China's sociopolitical system remains more of a communist state than it has become a socialist, however its economic system inclines towards capitalism with "Chinese characteristics" (Darlington 2017; Dimitrijević 2018), allowing the country a wider access to open markets (socialist market economy).

Inequalities in the world are not only defined by geographic position but are the consequence of decisions made. Economic science frequently disregards politics, although it makes a connection and essentially explains inequalities in the world (Acemoglu \& Robinson 2014; Bulatović - Vučićević 2019). Therefore, economic association is not just an economic but also a political phenomenon of the world's economic relations.

\section{SERBIA'S ROLE IN THE NETWORK OF GLOBAL INTERESTS}

Serbia's foreign trade and foreign policy, like in many other countries, is not determined only by its internal policy or cultural affinities, it is also defined by international surrounding the country is facing.

China provides assistance to Serbia but also to other countries in the world. Chinese-Serbian cooperation proceeds through numerous forms of support to Serbia. However, it is necessary to observe differences in official support governed by the state, directed to concrete development goals based on concessional

7 According to Yi Fuxian's research, researcher at the University of Wisconsin-Madison, in 2018, for the first time in 70 years, China had a decrease in population by 1,27 million.

8 China has the largest purchasing power parity and is also the largest exporter (quotes from the important world's institutions, magazines and daily press: World Economic Outlook, International Monetary Fund, Daily Telegraph, The Guardian). China's economic growth rate was $6.9 \%$ in 2017 , relying on increased export, industrial production growth and tough real estate market. 
loans or investment projects under government's leadership, not explicitly directed towards wider development goals (Zhang, 2016). Besides, unlike the European Union and the United States of America, China does not set up any political conditions for the offered support, at least not in the sense of moving toward a certain concept (such as ,the rule of law"), giving priority to provision of funds in the form of investment in Chinese interests, encouraging certain conduct of Serbian authorities (See: the European Union - Study: "Serbia's Cooperation with China, the European Union, Russia and the United States of America", 2017.).

The sea route of the New Silk Road goes from Chinese provinces ${ }^{9}$ to the Inidian Ocean (to Nairobi) then turns towards the Horn of Africa and continues to the Red Sea and the Mediterranean, stopping in Athens to connect to the European Belt of the New Silk Road in Venice (Simić 2015:197-198; Dimitrijević 2018:49-67). Economic belt of the New Silk Road includes the land and maritime trade road (Simić 2015:197). The map of the New Silk Road is not just reminding of significance of the former Silk Road but it should awake the awareness on China's friendly politics towards its neighbors (Tiezzi 2014, Simić 2015).

Through a global network of infrastructure projects ${ }^{10}$, China aims at deepening its relationships with neighboring countries and jointly developing a sub-regional network within Asia, also intending to link it with infrastructure networks of other continental sub-regions building that way the longest economic land corridor of the world (World Lend-Bridge), which according to the current plan includes over 60 countries on different continents (People's Republic of China: "The 13th Five-Year Plan for Economic and Social Development of the People's Republic of China 2016-2020"2015) ${ }^{11}$. The New Silk Road strategy aspires to increase revival of the large portion of the world covering a wide area with more than 4,4 billion people and production capacity of 21 trillion US\$ that is close to $1 / 3$ of World's GDP (Janković 2016, p.6.). Implementation of the New Silk Road strategy and the "One Belt One Road" initiative should contribute towards connecting with the existing development initiatives of regional organizations like the Shanghai Cooperation Organization, the Eurasian Economic Community (EurAsEC), the Association of Southeast Asian Nations

9 Those are: Fujian, Guangdong, Guangxi and Hainan.

10 Refers to corridors between: 1) China, Mongolia and Russia, 2) China, Central Asia and West Asia, 3) China and the Inodkina Peninsula, 4) New Eurasian Land Bridge, 5) China and Pakistan and 6) Bangladesh, China, India and Myanmar

11 At the end of May 2015, China Development Bank announced that the value of the project under the initiative for the construction of the economic belt and Silk Road of XXI century amount to about 900 billion dollars and will cover 900 projects in 60 countries. The bank also said that more than $\$ 10$ billion has already been invested in about fifty energy, mining and telecommunications projects .. 
(ASEAN), the Asia-Pacific Economic Cooperation (APEC), the Asia-Europe Meeting (ASEM), BRICS countries ${ }^{12}$ (Janković 2016, p.8.). Achieving the strategic goals of the New Silk Road will also include connecting the participant countries in the activities of international and regional financial institutions, above all the activities of the Asian Infrastructure Investment Bank (AIIB) and the New Development Bank (NDB), equivalents to the transatlantic system of monetary economics conducted by: the World Bank (WB), the International Monetary Fund (IMF) and the Asian Development Bank (ADB) (See: H. Zepp-LaRouche 2015:3, Dimitrijević 2018).

\section{Image 1: New Silk Road}

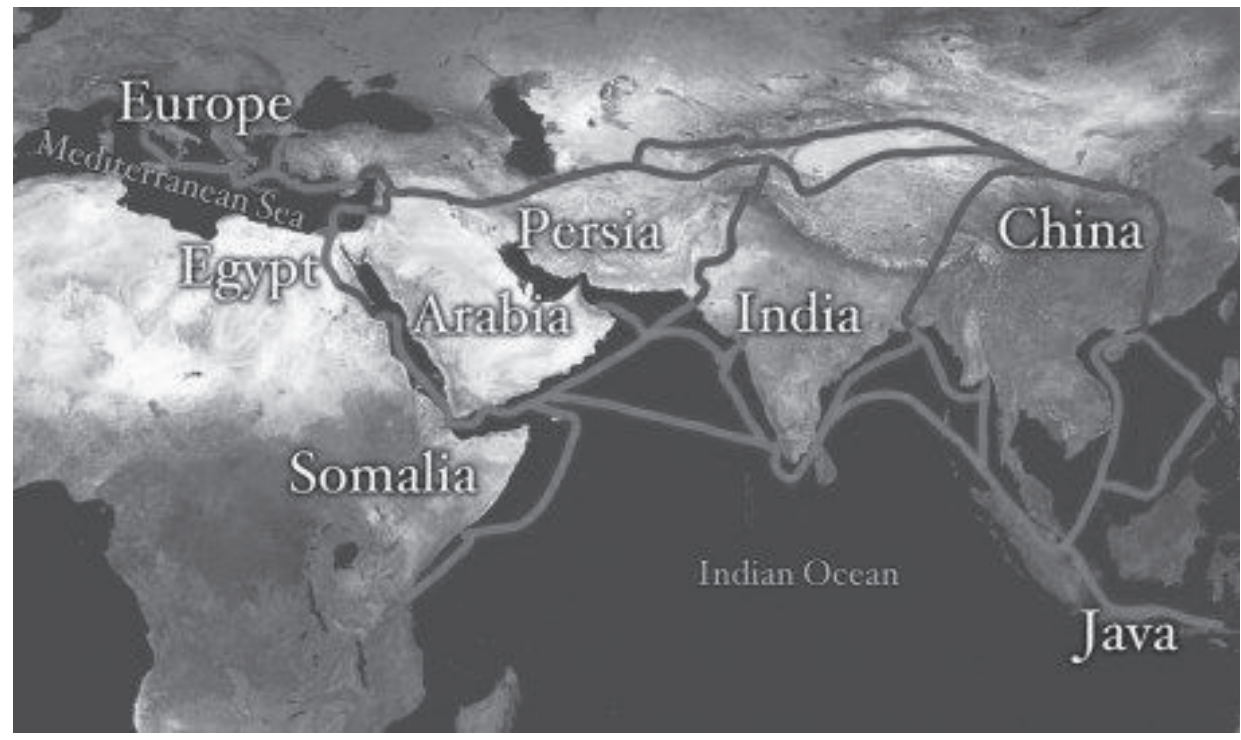

Source: www.tandfonline.com

It is important to notice that the New Silk Road strategy does not deny utilization of existing structures or development of new mechanisms of cooperation among the participating countries where Serbia has a significant role and place. Such cooperation is supposed to be a part of the New Silk Road strategy and, according to the Chinese political doctrine, includes three possible scenarios. The first scenario implies "development in phases" - meaning implementation of the strategy at regional level and then bolstering cooperation with Central and Eastern Europe countries. Second scenario involves "development of corridors"emphasizes the importance of development of corridors through Central Asia as a key element in development of the European Belt of the New Silk Road. Third scenario provides "equal development between East and West”, that is

12 Brazil, Russia, India, China, South Africa 
between the regions of Asia and Europe, giving the Central and Eastern Europe countries an important role in its implementation, especially as a vanguard in further Chinese investment and trade expansion on the European Union market (Zuokui 2014). From the Chinese point of view, cooperation within the mechanism „16+1” is an influential factor of stronger partnership between China and the European Union. Underlining this element in the context of improved Serbia-China relationship implies a comprehensive harmonization of the ChineseEuropean strategic partnership ${ }^{13}$, as well as achieving the goals of the Strategic Agenda for Cooperation 2020 (China-EU 2020 Strategic Agenda for Cooperation) (Pavlićević 2015:12).

Chinese investments in Serbia are dominantly an eclectic mixture of foreign investments under government's leadership and the high profile investment projects funded on a bilateral basis. It should be noted that China's project funding (as well as Russian) is more loan oriented instead of grants, which means that Serbia will finally have to pay its current spending from the Chinese sources ${ }^{14}$.

European Commissioner for European Neighborhood Policy and Enlargement Negotiations, Johannes Hahn, who is supervising the process of EU enlargement also expressed concerns about socioeconomic and financial impact the Chinese investments could have in the Balkans. Moreover, European officials are warning that loans and investments may also produce serious problems and headaches as countries in the region could be dragged into a labyrinth of loans that in reality cannot be cost effective, which would additionally increase their debt burdens as well as Chinese economic and political influence on them. There are concerns on the European side that Chinese investment model, which does not include insisting the countries receiving investments take an obligation of fighting against corruption or limited press freedom, will challenge the Brussels's goals in the region. There is a question if China progressively invests in the region for exactly that reason. It is undisputable that China increases its investments in the Balkans. During the last six years China has made significant investments in infrastructure, taking a position of an equal rival to the European Union $^{15}$ and making, at the same time, a significant influence.

13 In 2015, China made certain commitments towards the EU. Contribution of $€ 350$ billion to the Investment Plans for EU and commitments under the Memorandum of Understanding on an EU connecting Platform with China aimed at promoting cooperation in areas such as: infrastructure construction, equipment production, technologies and standard-setting.

14 For example: in the case of rail upgrading, using profits from rail traffic. Such loans are usually of a long-term nature and with low interest rates, but with embedded currency risk, which often means that they are made in US dollars.

15 A study by the German foundation Bertelsman „How the West invests along the Chinese New Silk Road“ indicates that Western countries are not lagging behind China in terms 


\section{FOREGIN DIRECT INVESTMENT GROWTH IN THE REGION}

The economic growth assessment should not only include GDP growth (Ivić-Mitić 2016:59) or similar growth indicators but also the impact of democratic and political freedoms on people's life and capacity (Sen 2016:150). The pace of technological changes, political polarities and fragile economic recovery expects us to define, estimate and implement new ways to the growth and progress. Achieving equality, sustainability and growth is possible only in global alliance, creating a model of economic progress that promotes higher standard of living for all and does not leave a weak foundation for future generations.

In the Western Balkans region and before the 2008 crisis culminated, the countries of the region had faced the number of problems, such as: economic transformation, macroeconomic instability, political misadventures, and manifested through the outbreak of war and the imposition of sanctions (Golubovic 2009). When the crisis culminated, it quickly transferred from the financial to the real sector, the consequences of which were felt in the region, including Serbia. Such changes were reflected in capital outflows, lack of demand and a fall in exports and a decrease in investment (Paunovic, Dimic, Arsenijevic 2018). In addition to the problems accompanying the financial crisis, Serbia was accompanied by the already existing problems of the Serbian economy of a macroeconomic nature - a high budget and foreign trade deficit.

Foreign direct investment (FDI) in 2018, in transition countries, declined mainly due to the fall in Russia (where the inflow is halved), Azerbaijan and Kazakhstan. The unfavorable investment climate, on the one hand, is a reflection of investor caution and, in the second place, due to weak GDP growth. The world recorded the lowest level of foreign direct investment in 2018 (investments fell to \$ 1.300 billion, or 13\%), which is the largest drop since the global financial crisis. According to UNCTAD, in the more developed economies FDI declined by $27 \%$ (the lowest level since 2004), while in developing countries, foreign direct investment is estimated as stable and recording a growth of $2 \%$.

According to the report, the Western Balkans region ${ }^{16}$, achieved a growth of $33 \%$. The inflow of foreign investment in the region for the years 2013-2018 in millions of dollars is shown in Image 2.

of investing in the said belt. This is supported by the fact that in the period 2013-2017, Western countries invested \$ 290 billion in the Silk Road countries, while China invested close to $\$ 285$ billion in that period. It also states when it comes to Serbia, that Western investment amounted to nearly $\$ 10$ billion in that period.

16 Refers sto SE Europe and wider region of transition economies. 
Image 2: FDI in the West Balkan region for the period 2013-2018 in mill. \$

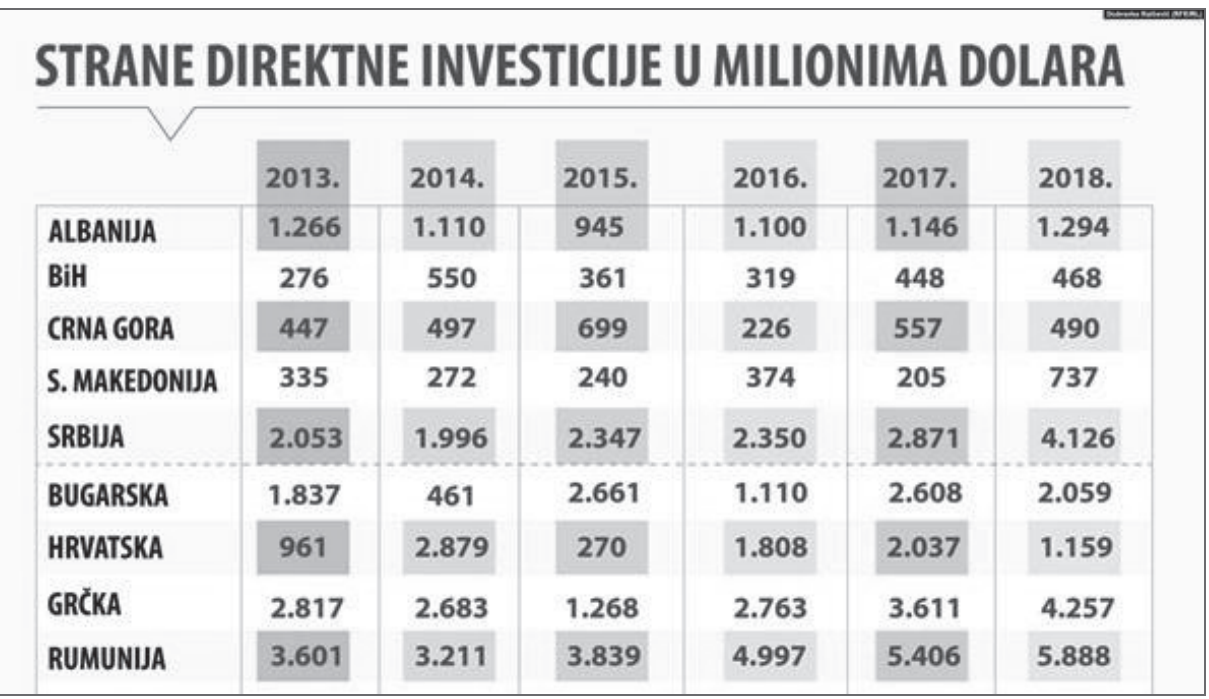

Source: https://impulsportal.net/index.php/vijesti/ekonomija/19300-izvjestaj-un-a-o-investicijama -na-balkanu-kolika-su-ulaganja-u-bih (28.07.2019.)

It can be seen that the inflow of foreign direct investment in the countries of the region is the highest for Serbia. Serbia had an increase of \$ 4.1 billion or an increase of $44 \%$. While Montenegro is the only one in the region to have fallen by $12 \%$ or $\$ 490$ million. The increase in foreign direct investment was recorded by Albania at $\$ 1.3$ billion, an increase of $13 \%$ and Bosnia and Herzegovina by $\$ 468$ million or an increase of $4 \%$. In Northern Macedonia, FDI inflows have risen to a high of $\$ 737$ million so far. ${ }^{17}$

The inflow of foreign direct investment from countries in the region, which are members of the European Union, is as follows: Slovenia has an increase of \$ 1.4 billion or $81 \%$, followed by Greece with 4.3 billion. \$ or an increase of $9 \%$ and Romania of $\$ 5.9$ billion or $9 \%$. In contrast, Croatia had a drop in foreign direct investment to 1.2 billion. \$ or a decline of $43 \%$, and in Bulgaria the decline was $\$ 2$ billion. or a $21 \%$ drop.

In addition to its favorable geographic location, Serbia has natural resources (especially copper) that attract foreign companies, and with strong infrastructure support, can become a leader in the region. ${ }^{18}$

17 The majority of investments relate to automotive (export-oriented) clusters in technology and industrial development zones, such as the Skopje Free Zone, which have attracted US automotive spare parts manufacturer Dura Automotive Systems.

18 In Serbia, the major share of foreign direct investment relates to Nikola Tesla Airport and the share of French Vanci Airports, as well as to the Bor mine and the share of Chinese Zijin. Then, the investment of British Essex Europe and Japanese Yazaki in the Serbian car cluster, as well as the investments of German tire manufacturer Continental in a research center in Novi Sad. 
The World Bank in its Western Balkans - Regular Economic Report, in a chapter called "Rising Uncertainties", cut Serbia's GDP growth forecast to 3,3\% and its anticipated mid-term growth to $4 \% .{ }^{19}$ The World Bank projected Serbia's 2020 GDP growth at 3,9\%, and 3,6\% average growth for the West Balkans. The World Bank Country Manager for Serbia Stephen Ndegwa confirmed at the report presentation that Serbia's economy is based on a "solid foundation" and reforms are moving in the right direction, however the economy could produce better results than the results achieved. It requires, as he mentioned, several reforms that would make possible a mid-term economy growth of 5 to $7 \%$. Besides, they estimate that consumption and investment in Serbia, although strong, will not be sufficient to compensate for the consequences of slowdown in exports caused by decreased economic activities of its main trade partners, primarily Italy but Germany as well. The experts warn that if Serbia wants to maintain competitiveness it should be proactive and make decisions in line with GDP growth and inflation rate, not beyond that (increase of salaries in the public sector $).^{20}$

\section{CONCLUSION}

Global economy is changing extensively. International economists present several options for the future global economic trends in dominant positioning of leading economies. Some economists' projections see China as the number one economy by 2041, even earlier according to others, anticipating China to be the largest economy by the end of third decade of the $21^{\text {st }}$ century.

Small, open economies, like Serbia's economy, depend on access to big markets. Current conditions on capital markets provide an opportunity for "easy and cheap" access to global financing but also the need for caution in fiscal management and permanent financial discipline. Uncertainties that might occur on the global market will change these conditions very quickly. Serbia has achieved the fastest growth; however it is important to maintain it. The risks for global growth are definitely negative. Among the negative risks, there are

19 The World Bank: Western Balkans - Regular Economic Report No.16 "Rising Uncertainties", Fall 2019.

20 World Bank economist in Belgrade, Lazar Sestovic, said that it is good that foreign direct investment, which amounted to 1.8 billion euros in the first half of the year, is $28 \%$ more than in the same period last year, which is more than enough to finance the current account deficit. According to him, it would be better for public sector wages to be increased in line with GDP growth and inflation, and not more than that, as decided by the Government. Also, Galina Andronova Winselet, Head of Sector at the World Bank for Macroeconomic Policies in Europe and Central Asia, warned that the Government of Serbia should strive to maintain the competitiveness of the economy and that the announced increase in profits should not contribute beyond real possibilities. 
intensified trade tensions or other political uncertainties that could affect investments and even aggravate unpredictability in financial and commodity markets. The anticipated growth of 3,5\%, is reduced to 3,3\% due to less favorable global trends affecting all economies. Also, the increased consumption had an impact on import expansion, which along with the reduced exports (due to economic slowdown, particularly in Italy) contributes to financial imbalance. Escalation of trade tensions between the United States of America and Europe affecting the automobile industry may disturb strongly integrated value chains in the West Balkans, especially in Serbia and North Macedonia. The announced public sector salary growth will have an impact in that sense and will probably increase the deficit. Some encouraging projections indicate possible better results than those achieved so far as foreign direct investments in developing countries, including Serbia, are stable with the reached growth of $2 \%$.

Serbia's economy is the largest in the sub-region and is relatively diversified, with strategic position that facilitates logistic infrastructure, and with continued judicial and institutional reforms, improvement of the financial sector regulations, stronger support to small and medium-sized enterprises and simplified trade are elements of the mid-term economy growth of 5\% to $7 \%$.

\section{LITERATURA}

Acemoglu Daren \& Robinson A. James (2014): “Why nations fail” - “Zašto narodi propadaju”, CLIO Beograd, 2014., str. 81., prevod sa engleskog Đorđe Trajković i Stefan Trajković Filipović

Avramović Nenad M., Đukić Stanimir B. (2018): „Strana direktna ulaganja, motivi, rizici i dupli standardi“ časopis Baština sv. 46., Priština - Lpeosavić, 2018., str. 77-91.

Bulatović Anka, Vučićević Lidija (2019): „Institucionalni okvir kao poluga razvoja“- Zbornik radova: „Modeli razvoja, iskustva drugih i naše mogućnosti“, Međunarodni naučni skup, Tom I, Evropski univerzitet Brčko Distrikt, Brčko 2019. strana 318.

Darlington Roger (2017): “A Short Guide to the Chinese Political System”, www. rogerdarlington.me.uk/Chinese politicalsystem, 27/09/2017 (u Dimitrijević Duško: „Odnosi Srbije i Kine na početku 21. veka“ https://www.researchgate.net/publicatio n/324064440DOI:https://doi.org/10.2298/MEDJP 1801049D

Dimitrijević Duško: „Odnosi Srbije i Kine na početku 21. veka“ https://www.researchgate.net/ publication/324064440DOI:https://doi.org/10.2298/MEDJP1801049D

Dimitrijević Duško (2007): „Privremena uprava Ujedinjenih nacija na Kosovu i Metohiji i zaštita imovinskih prava”, Teme, knjiga XXXI, br. 3, 2007., str. 473-510.

Dimitrijević Duško (2017): “Chinese Investments in Serbia-A Joint Pledge for the Future of the New Silk Road”, Baltic Journal of European Studies, vol. 7. No. 1(22), 2017.

Golubović Nataša (2009): „Anatomija globalne finansijske krize i implikacije za zemlje Centralne i istočne Evrope“ Teme 33 (2) str. 471-491. http://teme2.junis.ni.ac.rs/ public/journals/1/previousissues/teme2-2009/teme2-2009.htm

Evropska komisija EU: „Evropa 2020-Evropska strategija za pametan, održiv i uključiv rast“, Bruxelles, 3 March 2010. 
Evropski parlament EU (2017): “Saradnja Srbije sa Kinom, Evropskom Unijom, Rusijom i Sjedinjenim Američkim Državama“, Novembar 2017., EXPO_STU(2017) 603854 XL.pdf (28.10.2019.)

Hongzhou, Zhang: "Building the Silk Road Economic Belt - Problems and Priorities in Central Asia”, About the Institute of Defence and Strategic Studies, S. Rajaratnam School of International Studies, Nanyang Technological University, Singapore

https://impulsportal.net/index.php/vijesti/ekonomija/19300- izvjestaj-un-a-o-investicijamana-balkanu-kolika-su-ulaganja-u-bih (28.07.2019.)

https://bif.rs/2019/06/rast-direktnih-stranih-investicija-na-zapadnom-balkanu-makedonijana-prvom-mestu-sa-uvecanjem-od-260-u-srbiji-44/ (28.07.2019)

https: / / www.slobodnaevropa.org/a/kineske-investicije-i-doma\%C4\%87e-glavobolje/ 29874983.html (23.09.2019.)

https://ba.ekapija.com/news/2625513/smetaju-li-eu-kineske-investicije-na-zapadnombalkanu (23.09.2019.)

https://rs.seebiz.eu/trgovinski-rat-znacajno-smanjio-kineske-investicije-u-europi/ar-197276/ (23.09.2019.)

https://www.danas.rs/ekonomija/dw-ko-vise-investira-u-srbiju-kina-ili-eu/ (23.09.2019.)

https://www.nspm.rs/savremeni-svet/ekonomski-pojas-duz-puta-svile-i-pomorski-put-svileza-xxi-vek-retrospektiva.html?alphabet=l (23.09.2019.)

http://www.cepii.fr/PDF_PUB/pb/2016/pb2016-12.pdf (23.09.2019.)

https://www.politika.rs/sr/clanak/420831/Ekonomija/MMF-smanjio-procene-rastaglobalne-ekonomije (21.1.2019.)

https://china-cee.eu/themes/serbia/ (09.10.2019.)

https: / / bankar.rs/2019/10/09/sestovic-pogorsanje-u-globalnoj-ekonomiji-ce-uticatinaplasman-nase-robe-i-na-priliv-stranih-direktnih-investicija/(09.10.2019.)

https://impulsportal.net/index.php/vijesti/ekonomija/19300-izvjestaj-un-a-o-investicijamana-balkanu-kolika-su-ulaganja-u-bih (28.10.2019.)

https://www.slobodnaevropa.org/a/kineske-investicije-i-doma\%C4\%87e-glavobolje/29874983. html (09.11.2019.)

https://www.slobodnaevropa.org/a/vatromet-kineskog-uticaja-na-balkanu/29845758.html (09.11.2019.)

https://investitor.me/2019/04/03/balkanski-put-svile-5-milijardi-dolara-kineskih-investicijau-pet-zemalja-jugoistocne-evrope-ukljucujuci-i-crnu-goru/ (28.10.2019.)

https://srpskainfo.com/istocni-div-zabrinuo-brisel-kineske-investicije-sansa-ili-opasnost-zabalkan/ (28.10.2019.)

http://www.bertelsmann-transformation-index.de/Institute for Security \& Development Policy: „The Belt \& Road Initiative“, Backgrounder- October 2016

http://isdp.eu/publication/belt-road-initiative/ (09.11.2019.)

Ivić Mladen, Mitić Branislav (2016): „Makroekonomija i globalni izazovi“, Univerzitet za poslovni inženjering i menadžment Banja Luka, 2016.

Janković Aleksandar (2016): “New Silk Road-New growth engine”, The Review of International Affairs, No. 1161, 2016.

Paunović S. Svetislav, Dimić S. Maja, Arsenijević M. Olja (2019): „. “Analysis of socio-economic movements in Serbia in the circumstances of crisis”, Bastina 48., Priština-Lpeosavić, 2019., p.153-169

Pavlićević Dragan (2015): “China’s New Silk Road Takes Shape in Central and Eastern Europe”, China Brief, Volume XV, Issue 1, 2015. 
People's Republic of China (2016):“The 13th Five-Year Plan for Economic and Social Development of the People 's Republic of China (2016-2020)”, Compilation and Translation Bureau, Beijing, 2016.

Sen Amartya K (2016).: „Razvoj kao sloboda“, Algoritam, Zagreb, 2016.

Simić Jasminka (2015): “The economic belt of the New Silk Road: Chinese western west or answer to the Asian challenges", Vol. LXVII, International problems No. 2/3, p. 196216, DOI: 10.2298/MEDJP1503196S https://docplayer.net/ 38811417-Ekonomskipojas-novog-puta-svile-kineski-prodor-na-zapad-ili-odgovor-na-azijske- izazove.html (24.10.2019.)

Svetska banka: Zapadni Balkan-Redovni ekonomski izveštaj broj 16 "Rastuće neizvesnosti” jesen 2019. WEBRER16SRB (https://www.worldbank.org/en/region/eca/publication/ western-balkans-regular economic-report (23.09.2019.)

Tančić J. Dragan, Gordić L. Miodrag, Tančić D. Petar (2018): „Determing the effect of the refugee crisis on the security levels of small states using the dematel method" Bastina 44., Priština-Lpeosavić, 2018., p. 403-415.

Tiezzi Shannon (2014): “China's 'New Silk Road' Vision Revealed”, The Diplomat, 9 May 2014, http://thediplomat. com/2014/05/chinas-new-silk-road-vision-revealed/; (u Dimitrijević Duško: „Odnosi Srbije i Kine na početku 21. veka“ https:// www.researchgate.net/publication/324064440 DOI: https://doi.org/10.2298/ MEDJP1801049D)

UNCTAD (2019):„Izveštaj investicija u svetu 2019“ https://bif.rs/2019/06/rast-direktnihstranih-investicija-na-zapadnom-balkanu-makedonija-na-prvom-mestu-sa-uvecanjemod-260-u-srbiji-44 / (28.07.2019.)

"World Population Prospects: the 2017 Revision", UN Department of Economic and Social Affairs, ESA/P/WP/248, 2017., https://esa.un.org/unpd/wpp/publications/Files/ WPP2017KeyFindings. pdf

Ye Min: "China and Competing Cooperation in Asia-Pacific: TPP, RCEP, and the New Silk Road," Asian Security 11, no. 3 , 2015, p. 206-224.

Zepp-LaRouche H.(2015):“The New Silk Road Leads to the Future of Mankind!”, The New Silk Road becomes the World Land-Bridge, EIR News Service Inc., Washington, 2015.

Zhang Junyi: Chinese Foreign Assistance, Explained. Brookings Institution 'Order from Chaos' blog, July 19, available at htps://www.brookings.edu/blog/order-fromchaos/2016/07/19/chinese-foreign-assistance -explained/.(28.07.2019.)

Zuokui Liu:"The Role of Central and Eastern Europe in the Building of Silk Road Economic Belt”, China Institute of International Studies, 2014, http://16plus1thinktank.com /1/20160111/1096 html, 05/06/2017. 


\section{АиАија Н. ВУЧИЋЕВИЋ}

Анка С. БУААТОВИТ

\section{ИНВЕСТИЦИОНИ ТОКОВИ СРБИЈЕ У МРЕЖИ ГАОБААНИХ ИНТЕРЕСА}

\section{РеЗИме}

Значај страних инвестиција као облика финансирања не огмеАа се само на глобалном нивоу, него и на индивидуалном, националном нивоу привреда појединих земања. У последње Аве Аеценије, српска спољна економска и политичка Аешавања, прошла су кроз колебьиву али истрајну борбу за интегрисање у светске економске токове. Генерално посматрано, може се рећи Аа постоји размика у мотивационим факторима инвеститора, али и укупним ефектима који свој утицај испољавају на платни биланс земье домаћина у зависности оА начина инвестирања капитала. Србија гради партнерске односе, а сваки њен партнер има специфичан интерес и компаративну предност у земьи, те Аоприноси бољем позиционирању Србије у савременим међународним односима. Циь рада је Аа укаже на економско повезивање Србије са земњама са којима највише сарађује у послеАњих неколико гоАина и извлачење поука у периоду економског трансформисања и билатералног повезивања.

Кьучне речи: инвестициони токови, глобални интерес, стратегија, економија, политика.

РаА је преАат 22. Аецембра 2019. године, а након мишьења рецензената, оАлуком одговорног уредника Баштиине, одобрен за штампу. 